\title{
Pengaruh Usia, Pengalaman Kerja, Tingkat Pendidikan, dan Kompleksitas Tugas terhadap Efektivitas Pengguna Sistem Informasi Akuntansi
}

\author{
Putu Widya Anjani ${ }^{1}$ \\ Ni Gusti Putu Wirawati ${ }^{2}$
}

${ }^{1}$ Fakultas Ekonomi dan Bisnis Universitas Udayana (Unud), Bali, Indonesia email: nikitaanjani13@gmail.com/Telp: +62 87862225776

${ }^{2}$ Fakultas Ekonomi dan Bisnis Universitas Udayana (Unud), Bali, Indonesia

\begin{abstract}
ABSTRAK
Setiap perusahaan membutuhkan pengelolaan yang baik dalam menjalankan usahanya agar tujuannya tercapai dengan baik. Pihak manajemen membutuhkan informasi yang akurat dari sistem informasi akuntansi. Tujuan diadakannya penelitian ini adalah untuk mengetahui pengaruh usia, pengalaman kerja, tingkat pendidikan, dan kompleksitas tugas terhadap efektivitas pengguna sistem informasi akuntansi. Sampel yang digunakan berjumlah 69 responden dengan metode purposive sampling. Pengumpulan data dilakukan dengan kuisioner dan wawancara. Teknik analisis data yang digunakan adalah analisis regresi linier berganda. Hasil analisis menunjukan bahwa usia dan kompleksitas tugas berpengaruh negatif, sedangkan pengalaman kerja dan tingkat pendidikan berpengaruh positif terhadap efektivitas pengguna sistem informasi akuntansi. Untuk meningkatkan efektivitas pengguna sistem informasi akuntansi penting untuk memperhatikan faktor-faktor kemampuan karyawan dan mengadakan pelatihan untuk karyawan agar pengetahuan karyawan merata.
\end{abstract}

Kata kunci : Usia, pengalaman kerja, tingkat pendidikan, dan kompleksitas tugas.

\begin{abstract}
Every company needs a good management in running its business to achieve its goals well. Management needs accurate information from accounting information systems. The purpose of this study was to determine the influence of age, work experience, education level, and task complexity to the effectiveness of the accounting information system user. The sample used to be 69 respondents with purposive sampling method. Data was collected through questionnaires and interviews. The data analysis technique is used multiple linear regression analysis. The result of the analysis shows that age and task complexity have the negative effect, while the work experience and education level have a positive effect on the effectiveness of users of accounting information system. To improve the effectiveness of users of accounting information systems it is important to pay attention to employee ability factors and conduct training for employees so that the knowledge of the employees is evenly distributed.
\end{abstract}

Keywords : Age, work experience, education level, and task complexity.

\section{PENDAHULUAN}

Setiap organisasi, entitas atau perusahaan dalam menjalankan usahanya membutuhkan pengelolaan yang baik agar tujuannya dapat tercapai dengan baik. 
Untuk mencapai tujuan tersebut, tentunya pihak manajemen membutuhkan informasi akurat yang didapatkan dari sistem informasi akuntansi. Sistem informasi akuntansi atau sistem akuntansi merupakan kumpulan sumber daya, seperti manusia dan peralatan, yang dirancang untuk mengubah data keuangan dan data lainnya ke dalam informasi yang akan dikomunikasikan kepada para pembuat keputusan (Bodnar dan William S, 2006:3).

Miller, dkk (2016) mengatakan bahwa selama bertahun-tahun, akuntansi telah berkembang menjadi sistem yang jauh lebih kompleks dan melibatkan aktivitas rumit, seperti menghitung pajak, mengaudit laporan keuangan dan memproses daftar gaji untuk banyak karyawan. Akan masuk akal untuk berpikir bahwa teknologi maju, seperti sistem informasi akuntansi hanya akan meningkatkan kegiatan suatu organisasi.

Suatu organisasi, entitas, atau perusahaan tentunya harus memiliki sistem informasi akuntansi yang baik untuk menghindari berbagai macam tindakan penyimpangan atau pun kesalahan-kesalahan. Dengan adanya sistem informasi akuntansi yang baik dan juga karyawan yang dapat menggunakan sistem informasi akuntansi dengan efektif mengantisipasi penyimpangan yang mungkin terjadi. Seiring dengan berkembanganya teknologi dan informasi, banyak hal yang awalnya dilaksanakan secara manual beralih menjadi hal yang berbasis komputer. Pengolahan data akuntansi yang berbasis komputer pun sudah terbukti dapat memberikan informasi yang lebih andal. Ilirjan, dkk (2015) menyatakan bahwa sistem informasi akuntansi memainkan peran yang sangat penting dalam 
pengelolaan operasi dan aktivitas perusahaan, dimana sistem informasi akuntansi berbasis komputer yang sangat diperlukan.

Koperasi memiliki peran penting dalam pembangunan ekonomi dan kesejahteraan masyarakat desa. Peran koperasi sendiri dapat ditingkatkan dengan adanya pemanfaatan sistem informasi akuntansi untuk memperlancar segala kegiatan yang dilakukan oleh koperasi. Untuk mencapai hal tersebut, kualitas dari pengguna sistem informasi akuntansi sangatlah diperlukan. Saat ini kegiatan yang dilakukan oleh koperasi sangatlah kompleks, seperti simpan pinjam, kredit usaha, dan juga mini market. Dalam pemanfaatan sistem informasi akuntansi, selain diperlukan sistem yang baik, tentunya juga diperlukan kualitas pengguna sistem informasi akuntansi yang baik dan efektif.

Terdapat beberapa koperasi bermasalah di Tabanan, di antaranya adalah Koperasi Sarining Arta dan Koperasi Sejahtera Mulya. Koperasi Sarining Arta mengalami kebangkrutan sebelum setahun berdiri sehingga belum pernah mengadakan Rapat Anggota Tahunan (RAT). Hal tersebut disebabkan karena terdapat oknum yang melakukan kecurangan, seperti karyawan yang menggelapkan uang. Tidak adanya RAT menyebabkan tidak adanya laporan RAT sehingga kasus ini sulit untuk diselidiki. Koperasi Sejahtera Mulya mengalami kebangkrutan karena adanya pinjaman fiktif dan juga kredit macet. Kasus-kasus tersebut masih diselidiki oleh pihak kepolisian. Koperasi seharusnya memiliki laporan berkala dalam waktu tertentu, dan memiliki ketentuan yang pasti mengenai kredit dan kegiatan lainnya. Mudahnya syarat untuk membuat koperasi menjadikan banyaknya koperasi yang bermunculan, namun tidak berkompeten. 
Putu Widya Anjani dan Ni Gusti Putu Wirawati. Pengaruh...

Orang-orang yang menjalankan koperasi pun terkadang tidak memiliki kemampuan yang sesuai dalam menjalankan koperasi. Laporan keuangan dan juga data-data lain seharusnya dibuat secara berkala dan terintegrasi. Data-data yang dibuat harus tegas sesuai aturan dan prosedur, sehingga dapat menghindari masalah, seperti pinjaman fiktif dan kredit macet.

Menurut artikel dari Bali News Network pada tanggal 12 Juni 2017, saat Rakerda Tahun Buku 2016 di KUD Penebel, dikatakan bahwa di Kabupaten Tabanan terdapat 559 unit koperasi. Dari jumlah tersebut, 524 koperasi aktif dan 35 koperasi tidak aktif. Jumlah anggota koperasi tercatat 89.077 orang, manajer koperasi 431 orang dan karyawan koperasi 2.859 orang. Perkembangan kelembagaan koperasi di Kabupaten Tabanan cukup baik. Selain berusaha untuk mendapatkan keuntungan untuk kelangsungan operasi koperasi, kinerja karyawan juga sangat penting terutama dalam penggunaan sistem informasi akuntansi. Penggunaan sistem informasi akuntansi yang baik tentunya akan mendukung kinerja koperasi dan mungkin dapat mengurangi jumlah koperasi yang tidak aktif.

Menurut Bonollo dkk., (2015), konfigurasi sistem informasi akuntansi tidak hanya mengenai masalah teknis, namun juga melibatkan keseluruhan manajemen. Penggunaan sistem informasi akuntansi yang baik akan membantu dalam menyimpan data keuangan atau data lainnya yang berhubungan dengan operasional koperasi dan memproses data untuk mengambil keputusan. Data-data nasabah yang sebenarnya dapat diproses dengan baik sehingga dapat menghindari adanya pinjaman fiktif. Informasi mengenai kredit yang terproses dengan baik juga dapat membantu dalam keputusan untuk menindaklanjuti jika ada kredit yang 
bermasalah. Srivastava dan Lognathan (2016), mengatakan, ketersediaan dan penggunaan informasi akuntansi yang memadai membantu manajemen dalam membuat keputusan yang efektif dan efisien, dan ini berpengaruh terhadap penggunaan informasi akuntansi sebagai bantuan untuk pengambilan keputusan manajemen di organisasi tersebut.

Karyawan seringkali menyimpang dari prosedur penggunaan sistem akuntansi yang menyebabkan ketidaksesuaian pada laporan keuangan. Karyawan merasa bahwa ia sudah melakukan proses yang benar, tetapi ternyata tidak. Hal tersebut mungkin saja terjadi dikarenakan oleh pemahaman dan pribadi masingmasing karyawan ataupun pengalamannya dalam menggunakan sistem akuntansi masih kurang. Selain itu, pekerjaan yang banyak dan menumpuk juga dapat mengganggu kosentrasi karyawan. Di sinilah perlu diperhatikan mengenai kinerja karyawan dalam menggunakan sistem informasi akuntansi. Penggunaan sistem informasi akuntansi yang baik tentunya mendukung kinerja koperasi dan dapat mengurangi kesalahan-kesalahan yang terjadi.

Menurut Uyar, dkk (2017) untuk menumbuhkan tata kelola perusahaan, para manajer harus menetapkan prosedur pelaporan internal serta perangkat pengendalian dan pemantauan internal sebelum mencoba pengendalian eksternal melalui audit independen. Hal tersebut didukung sistem informasi akuntansi yang memadai sehingga kegagalan akuntansi dan audit, serta penyalahgunaan oleh manajer dapat dihindari. Prasad dan Green (2015) menyatakan sistem informasi akuntansi memberikan informasi yang berharga bagi pengambil keputusan. Namun, dalam lingkungan yang berubah dengan cepat manajemen sistem 
Putu Widya Anjani dan Ni Gusti Putu Wirawati. Pengaruh...

informasi akuntansi berkelanjutan diperlukan bagi organisasi untuk mengoptimalkan hasil kerja. Ini berarti manajer dan karyawan harus dapat mengikuti perkembangan sistem informasi akuntansi yang nantinya akan terus diperbarui. Menurut Tazik dan Mohamed (2014) ketepatan waktu dianggap sebagai karakteristik kualitatif penting dari informasi keuangan. Pengguna informasi keuangan perlu mendapatkan informasi yang andal, relevan dan tepat waktu, agar. Selain mengerti dan paham dalam menggunakan sistem informasi akuntansi, penggunanya juga harus dapat bekerja dengan efektif sehingga pekerjaan yang dilakukan dapat selesai tepat pada waktunya.

Terdapat penelitian yang berhubungan dengan efektivitas pengguna sistem informasi akuntansi yang telah dilakukan. Vipraprastha dan Sari (2016) menyatakan bahwa pengalaman kerja, pelatihan, tingkat pendidikan, dan insentif berpengaruh positif terhadap efektivitas penggunaan sistem informasi akuntansi. Widyatmoko dan Pramudi (2011) sebelumnya melakukan penelitian mengenai penggunaan teknologi dan informasi dimana salah satu hasil penelitiannya menyatakan bahwa umur berpengaruh secara signifikan negatif terhadap penggunaan komputer. Sedangkan, penelitian dari Budiono (2011) menyatakan bahwa umur mempunyai hubungan yang tidak signifikan dengan keahlian dalam EUC. Adanya perbedaan tersebut menjadi alasan peneliti menggunakan variabel umur atau usia.

Selain itu, peneliti ingin menguji kembali variabel pengalaman kerja dan tingkat pendidikan. Hasil penelitian dari Widyantari dan Suardikha (2016) menyatakan bahwa pengalaman kerja dan tingkat pendidikan memiliki pengaruh 
positif dan signifikan pada kinerja individu pengguna sistem informasi akuntansi. Sedangkan Ayuni (2008) menyatakan bahwa pendidikan berpengaruh positif, namun tidak signifikan terhadap kualitas sistem audit dengan sistem informasi berbasis computer. Sedangkan pengalaman memiliki pengaruh negatif, namun tidak signifikan terhadap kualitas atas sistem informasi yang menggunakan basis komputer.

Parjanti, dkk (2014) mengatakan, sistem informasi akuntansi, gaya kepemimpinan, dan kompleksitas tugas berpengaruh dan signifikan terhadap kinerja karyawan. Dari penelitian ini, peneliti mengambil variabel kompleksitas tugas yang dianggap paling sesuai dengan perkembangan koperasi yang saat ini sudah memiliki banyak kegiatan usaha. Variabel dalam penelitian Parjanti dkk (2014) juga belum menunjukkan bagaimana arah dari pengaruh kompleksitas tugas terhadap kinerja karyawan.

Berdasarkan uraian tersebut, penulis tertatik untuk mengadakan penelitian terhadap bagaimana pengaruh faktor kinerja individual terhadap efektivitas penerapan sistem informasi akuntansi. Lokasi penelitian yang dipilih, yaitu koperasi di Kecamatan Penebel karena sebelumnya belum ada yang melakukan penelitian mengenai hal ini pada koperasi di Kecamatan Penebel. Penelitian ini berjudul "Pengaruh Usia, Pengalaman Kerja, Tingkat Pendidikan dan Kompleksitas Tugas terhadap Efektivitas Pengguna Sistem Informasi Akuntansi di Koperasi Kecamatan Penebel”.

Penelitian ini diharapkan mampu menambah bukti mengenai studi yang membahas "Pengaruh Usia, Pengalaman Kerja, Tingkat Pendidikan dan 
Kompleksitas Tugas terhadap Efektivitas Pengguna Sistem Informasi Akuntansi di Koperasi Kecamatan Penebel” yang mendukung Theory of Reasoned Action (TRA) serta Teori Technology Acceptance Model (TAM), juga sebagai sarana studi banding antara teori dalam perkuliahan dengan yang terjadi sebenarnya dalam dunia kerja. Penelitian ini juga diharapkan memberikan informasi bagi pengguna sistem informasi akuntasi agar lebih memahami faktor yang dapat berpengaruh pada efektivitas pengguna informasi akuntansi, terutama karyawan di koperasi Kecamatan Penebel.

Siswosoebrotho dan Daryanti (2013) mengatakan, niat melakukan atau tidak melakukan niat tertentu dipengaruhi oleh dua penentu dasar, yaitu sikap (attitude towards behavior) dan pengaruh sosial, yaitu norma subjektif (subjective norm). TRA menjelaskan hubungan intensi atau niat dengan perilaku yang sepenuhnya berada dalam kontrol individu (volitional behavior) sehingga asumsi dasar dari TRA adalah individu sadar dalam membuat keputusan untuk melakukan atau tidak melakukan suatu perilaku, jika individu tersebut menginginkannya.

Fatmawati (2015) menjelaskan bahwa TAM merupakan teori yang menggunakan pendekatan teori perilaku (behavioral theory). TAM merupakan model analisis untuk mengetahui perilaku pengguna akan penerimaan teknologi. Menurut Wikipedia, "TAM is an information systems theory that models how users come to accept and use a technology”. TAM merupakan suatu teori sistem informasi yang modelnya bagaimana pengguna datang untuk menerima dan menggunakan teknologi. Meneurut Khairi dan Baridwan 
(2015), persepsi teknologi informasi akan mempengaruhi sikapnya dalam sistem penerimaan dan penggunaan. Beberapa faktor yang bisa mempengaruhinya adalah pengguna persepsi tentang kegunaan dan kemudahan penggunaan sistem informasi. Dengan demikian, Tindakan atau perilaku orang tersebut akan menggunakan kegunaan yang dirasakan dan dirasakan kemudahan penggunaan sebagai tolok ukur.

Suartika dan Widhiyani (2017) mengatakan, efektivitas adalah suatu ukuran yang memberikan gambaran seberapa jauh target dapat dicapai, orientasinya adalah pada keluaran (output) yang dihasilkan. Menurut Pratama dan Suardikha (2013), sistem informasi akuntansi dapat dikatakan efektif harus memenuhi persyaratan, yakni informasi yang dihasilkan harus berkualitas dan harus berkaitan dengan output sistem informasi. Menurut Abduljalil dan Zainuddin (2015), sistem informasi akuntansi yang efektif dapat membantu untuk mengatasi masalah jangka pendek dan memantau arus biaya, pengeluaran, dan arus kas operasi.

Pengguna pertama output komputer adalah para karyawan administrasi di bidang akuntansi. Ketika perusahaan menerapkan sistem informasi manajemen, penekanan akan bergeser dari data menuju ke informasi dan dari karyawan administrasi ke pemecahan masalah (McLeod dan Schell, 2012;16). Menurut Seyal dan Rahman (2015), teknologi informasi dan sistem informasi saat ini sudah matang dan memberikan keuntungan kompetitif bagi organisasi. Namun, keberhasilan tersebut tetap bergantung pada penggunanya. Teknologi dan sistem informasi tidak dapat memberikan hasil yang positif, kecuali pengguna menerima, 
mengadopsi dan menggunakan teknologi serta sistem tersebut.

Sistem Informasi Akuntansi (SIA) merupakan kumpulan sumber daya, seperti manusia dan peralatan, yang bisa dirancang untuk mengubah data keuangan dan data lainnya ke dalam informasi (Bodnar dan William S, 2006:3).

Menurut Dwitrayani, dkk (2017), sistem informasi akuntansi merupakan sarana penting dalam organisasi bisnis untuk meningkatkan efisiensi dan mendukung daya saing dengan menyediakan informasi keuangan dan akuntansi bagi manajemen. Informasi yang dihasilkan akan bermanfaat dalam proses pembuatan keputusan, pembelian, instalasi dan penggunaan masingmasing sistem ketika manfaatnya lebih besar dari biayanya. Manfaatnya dapat dinilai dari perannya dalam meningkatkan proses pembuatan keputusan, kualitas informasi akuntansi, evaluasi kinerja, pengendalian internal, dan memfasilitasi transaksi perusahaan. Dengan melihat kelima karakteristik tersebut, efektivitas sistem informasi akuntansi menjadi penting bagi semua perusahaan.

Menurut Dandago dan Rufai (2014) sistem informasi akuntansi adalah subsistem informasi dalam sebuah organisasi yang mengumpulkan informasi dari berbagai subsistem entitas dan mengkomunikasikannya ke subsistem pemrosesan informasi organisasi. Sistem informasi akuntansi secara tradisional berfokus pada pengumpulan, pengolahan, dan komunikasi informasi yang berorientasi pada keuangan ke pihak internal (terutama manajemen). Namun saat ini, sistem informasi akuntansi berkaitan dengan data keuangan dan informasi non finansial maupun data keuangan. Menurut Ismail dan King (2007), penggunan sistem 
informasi akuntansi dan kinerja karyawan harus diselaraskan. Jika hal tersebut terwujud, tentunya akan dapat meningkatkan efektivitas pengguna sistem informasi akuntansi, yaitu karyawan itu sendiri.

Usia atau umur seseorang dapat diketahui bila tanggal, bulan, dan tahun kelahiran diketahui. Penghitungan umur menggunakan pembulatan ke bawah. Umur dinyatakan dalam kalender masehi (BPS, 2008 dalam Setiawan, 2010).

Menurut Morris dan Venkatesh (2000) mengenai perbedaan usia dalam penggunaan teknologi, keputusan penggunaan teknologi pekerja yang lebih muda lebih dipengaruhi oleh sikap terhadap penggunaan teknologi. Sebaliknya, pekerja yang lebih tua lebih dipengaruhi oleh norma subjektif dan kontrol perilaku. Hasil penelitian dari Budiono (2004) menunjukkan bahwa umur berpengaruh negatif terhadap EUC. Jika umur meningkat, maka keahlian EUC menurun. Menurut Vipraprastha dan Sari (2016), pengalaman adalah suatu faktor untuk menilai seberapa lama seseorang mengetahui atau bertukar pengetahuan dengan orang lain untuk bisa melaksanakan pekerjaannya secara efektif.

Widyantari dan Suardikha (2016) menyatakan bahwa terdapat pengaruh yang positif dari variabel pengalaman kerja pada efektivitas penggunaan sistem informasi akuntansi. Artinya, pengalaman kerja seseorang sangat mempengaruhi karakter dalam bekerja karena semakin lama seseorang bekerja dalam menggunakan sistem informasi akuntansi maka akan semakin baik kinerja seseorang dan membantu dalam proses penyajian informasi akuntansi.

Tingkat pendidikan adalah tahapan pendidikan yang ditetapkan berdasarkan tingkat perkembangan peserta didik. Tingkat pendidikan yang lebih 
tinggi akan memudahkan seseorang atau masyarakat untuk menyerap informasi dan mengimplementasikannya. Untuk meningkatkan kemampuan seseorang, diperlukan adanya pendidikan, misalnya pendidikan dari tingkat Sekolah Dasar (SD) hingga Sarjana (S1), (S2), (S3) sehingga pada saat pengambilan keputusan menjadi tepat dan akurat (Dwijayanthi dan Dharmadiaksa, 2013).

Dwijayanthi dan Dharmadiaksa (2013) menunjukkan bahwa tingkat pendidikan berpengaruh positif dan signifikan terhadap kinerja individu pengguna sistem informasi akuntansi. Hal ini berarti semakin tinggi tingkat pendidikan seseorang, maka akan semakin baik kinerja individu pengguna sistem informasi akuntansi.

Prajanti, dkk (2014) mengatakan bahwa kompleksitas tugas merupakan tugas yang kompleks dan rumit. Kompleksitas tugas dapat membuat seorang karyawan menjadi tidak konsisten dan tidak akuntabilitas. Menurut Supatmi dan Febrian (2014) kompleksitas merupakan tingkat dimana inovasi dipersiapkan sebagai sesuatu yang relatif sulit diartikan dan digunakan oleh individu. Semakin kompleks suatu inovasi maka semakin rendah tingkat penggunaannya. Jika teknologi dipersiapkan dalam kontek ini, maka hasilnya menunjukkan hubungan negatif antara kompleksitas dan pemanfaatan teknologi informasi. Kompleksitas dalam pemanfaatan teknologi digunakan untuk sesuatu yang bernilai tambah besar, dengan demikian meningkat pula produktivitas suatu pekerjaan yang disertai dengan peningkatan kinerja individual.

Menurut Baswir (2013:21), koperasi adalah suatu bentuk perusahaan yang didirikan oleh orang-orang tertentu untuk melaksanakan kegiatan-kegiatan 
tertentu berdasarkan ketentuan dan tujuan tertentu pula. Secara umum koperasi dipahami sebagai perkumpulan orang yang secara sukarela mempersatukan diri untuk memperjuangkan peningkatan kesejahteraan ekonomi mereka.

Menurut Hariwangsa dan Wirawati (2017) koperasi memiliki tujuan untuk memajukan kesejahteraan anggota pada khususnya dan juga masyarakat pada umumnya. Koperasi ikut membangun tatanan perekonomian nasional untuk mewujudkan masyarakat yang maju, adil dan makmur dengan berlandaskan pancasila dan UUD 1945 (UU RI No.25, 1992: Pasal 3). Untuk dapat mencapai tujuannya, pengelolaan koperasi harus dapat dilakukan dengan sebaik mungkin agar bisa diharapkan menjadi koperasi yang mampu bersaing dengan bentuk badan usaha lain sehingga bisa mencover ekonomi masyarakat di sekelilingnya dengan baik. Dari pengelolaan yang baik inilah maka tujuan koperasi untuk memajukan kesejahteraan anggota pada khususnya dan masyarakat pada umumnya akan tercapai.

Berdasarkan uraian yang telah dipaparkan, maka hipotesis yang dapat diajukan adalah :

$\mathrm{H}_{1}$ : Usia berpengaruh negatif terhadap Efektivitas Pengguna Sistem Informasi Akuntansi.

$\mathrm{H}_{2}$ : Pengalaman Kerja berpengaruh positif terhadap Efektivitas Pengguna Sistem Informasi Akuntansi.

$\mathrm{H}_{3}$ : Tingkat Pendidikan berpengaruh positif terhadap Efektivitas Pengguna Sistem Informasi Akuntansi.

$\mathrm{H}_{4}$ : Kompleksitas Tugas berpengaruh negatif terhadap Efektivitas Pengguna Sistem Informasi Akuntansi. 


\section{METODE PENELITIAN}

Pendekatan yang digunakan adalah pendekatan kuantitatif yang bersifat asosiatif. Penelitian asosiatif adalah penelitian yang bertujuan untuk mengetahui hubungan antara dua variabel atau lebih (Sugiyono, 2014:15). Variabel yang diuji pada penelitian ini adalah pengaruh usia, pengalaman kerja, tingkat pendidikan dan kompleksitas tugas terhadap efektivitas pengguna sistem informasi akuntansi. Kerangka konseptual dalam penelitian ini ditunjukan pada Gambar 1.

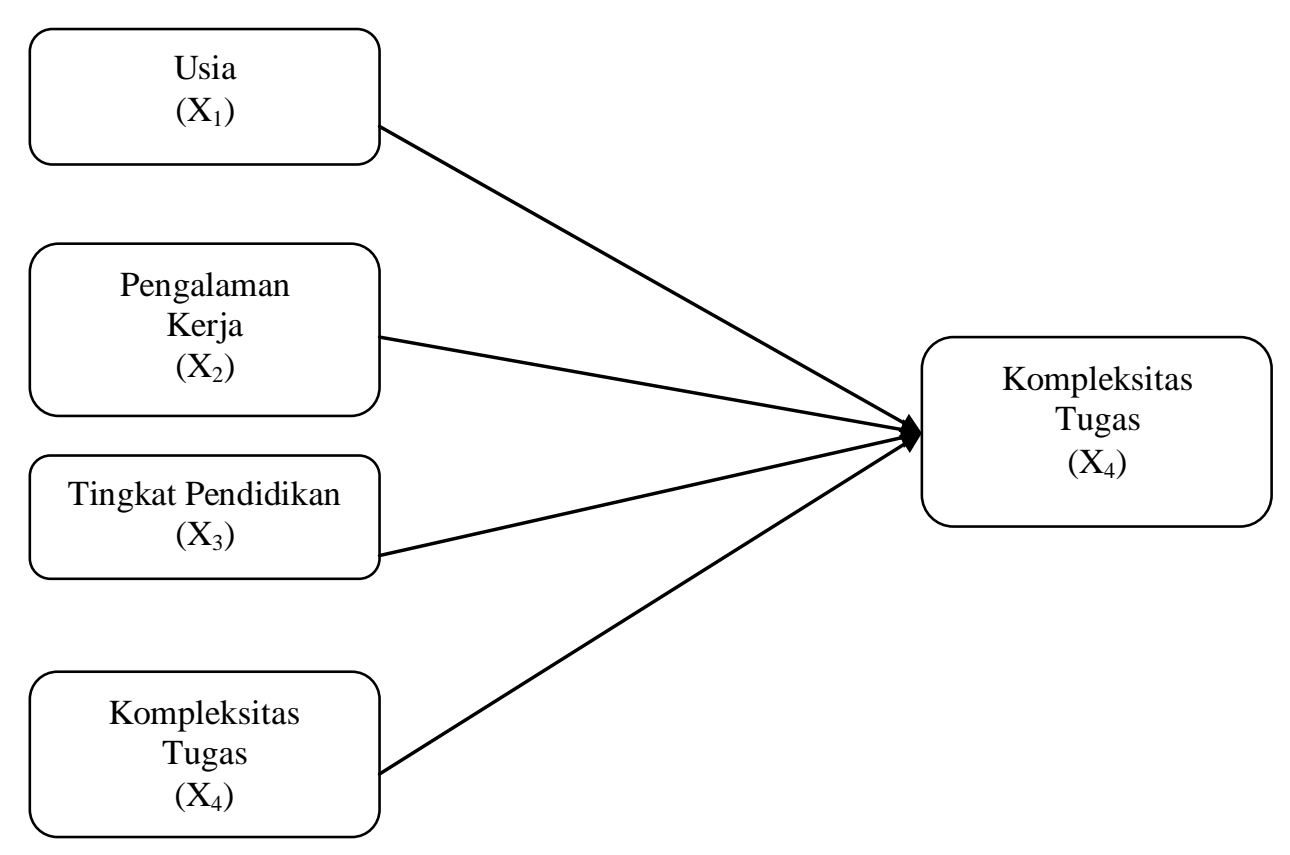

\section{Gambar 1. Kerangka Konseptual}

Lokasi penelitian ini dilakukan di koperasi Kecamatan Penebel. Lokasi ini dipilih karena belum ada pada penelitian sebelumnya yang meneliti tentang pengaruh usia, pengalaman kerja, tingkat pendidikan dan kompleksitas tugas terhadap efektivitas pengguna sistem informasi akuntansi di koperasi Kecamatan Penebel. Obyek dalam penelitian ini adalah pengaruh usia, pengalaman kerja, 
tingkat pendidikan dan kompleksitas tugas terhadap efektivitas pengguna sistem informasi akuntansi.

Menurut Indriantoro dan Supomo (2016:63) variabel independen adalah tipe variabel yang menjelaskan atau mempengaruhi variabel lain. Variabel independen dinamakan pula dengan variabel yang diduga sebagai sebab (presumed cause variabel) dari variabel dependen. Variabel bebas (X) dalam penelitian ini adalah usia dan tingkat pendidikan yang diukur dengan cara pengelompokkan untuk pemberian skor serta pengalaman kerja dan kompleksitas tugas yang diukur menggunakan skala likert.

Variabel dependen dalam penelitian ini adalah Efektivitas Pengguna Sistem Informasi Akuntansi (Y). Efektivitas pengguna sistem informasi akuntansi adalah ukuran yang menggambarkan seberapa jauh pencapaian target oleh pengguna sistem informasi akuntansi. Variabel efektivitas pengguna sistem informasi akuntansi diberikan dalam sepuluh pernyataan dan diukur dengan menggunakan skala likert.

Jenis data pada penelitian ini ada dua, yaitu data kuantitatif dan data kualitatif. Data kuantitatif adalah jumlah manajer dan karyawan yang bekerja di koperasi Kecamatan Penebel serta data kualitatif yang telah dikuantitatifkan menggunakan skala likert. Data kualitatif yang digunakan, yaitu daftar nama manajer dan karyawan yang terdapat di koperasi Kecamatan Penebel. Sumber data dalam penelitian ini ada dua, yaitu data primer dan data sekunder. Data primer, yaitu jawaban dari responden yang dijawab melalui kuesioner. Data sekunder, 
yaitu daftar nama manajer dan karyawan yang terdapat di koperasi Kecamatan Penebel.

Populasi (population) adalah sekelompok orang, kejadian ataupun segala sesuatu yang mempunyai karakteristik (Indriantoro dan Supomo, 2016:115). Populasi pada penelitian ini adalah manajer dan karyawan di koperasi Kecamatan Penebel yang memilik aset paling sedikit sebesar Rp 10.000.000.000,00 (sepuluh milyar rupiah). Jumlah koperasi yang memenuhi kriteria tersebut adalah sebanyak 4 koperasi dengan rincian sebagai berikut :

Tabel 1.

Jumlah Manajer dan Karyawan 4 Koperasi di Kecamatan Penebel

\begin{tabular}{lc}
\hline \multicolumn{1}{c}{ Nama Koperasi } & Jumlah Manajer dan Karyawan \\
\hline KUD. Penebel & 31 orang \\
KUD. Rejasa & 29 orang \\
KSP. Danu Jaya & 13 orang \\
Kopnak. Werdhi Sedana Merta & 6 orang \\
Jumlah & 79 orang \\
Sumber: Data diolah, 2017 &
\end{tabular}

Teknik penentuan sampel ditentukan teknik purposive sampling berdasarkan pertimbangan. Kriteria untuk pengambilan sampel dalam penelitian ini, yaitu manajer dan karyawan yang merupakan pengguna sistem informasi akuntansi di koperasi Kecamatan Penebel. Dimana, manajer dan karyawan pada 4 koperasi yang merupakan pengguna sistem informasi akuntansi adalah :

Tabel 2.

Jumlah Manajer dan Karyawan Pengguna Sistem Informasi Akuntansi pada 4 Koperasi di Kecamatan Penebel

\begin{tabular}{lc}
\hline \multicolumn{1}{c}{ Nama Koperasi } & Jumlah Manajer dan Karyawan \\
\hline KUD. Penebel & 30 orang \\
KUD. Rejasa & 29 orang \\
KSP. Danu Jaya & 13 orang \\
Kopnak. Werdhi Sedana Merta & 6 orang \\
Jumlah & 78 orang \\
\hline Sumber: Data diolah, 2017 &
\end{tabular}


Wawancara adalah teknik pengumpulan data yang menggunakan pertanyaan dan diajukian secara lisan. Teknik wawancara dilakukan untuk jenis pertanyaan yang jawabannya memerlukan penjelasan (Indriantoro dan Supomo, 2016:152). Metode pengumpulan data adalah kuesioner yang memberikan tanggungjawab kepada responden untuk membaca dan menjawab pertanyaan. (Indriantoro dan Supomo, 2016:154).

Teknik analisis data yang digunakan pada penelitian ini adalah analisis regresi linear berganda yang menguji bagaimana pengaruh variabel independen terhadap variabel dependen menggunakan skala pengukuran interval atau rasio dalam persamaan linear (Indriantoro dan Supomo, 2016:211). Adapun persamaan dari regresi linear berganda, yaitu :

$$
Y=\beta_{0}+\beta_{1} X_{1}+\beta_{2} X_{2}+\beta_{3} X_{3}+\beta_{4} X_{4}+e
$$

Keterangan :

$\begin{array}{ll}\mathrm{Y} & =\text { Efektivitas Pengguna Sistem Informasi Akuntansi } \\ \mathrm{X}_{1} & =\text { Usia } \\ \mathrm{X}_{2} & =\text { Pengalaman kerja } \\ \mathrm{X}_{3} & =\text { Tingkat pendidikan } \\ \mathrm{X}_{4} & =\text { Kompleksitas tugas } \\ \beta_{0} & =\text { Konstanta } \\ \beta_{1}, \beta_{2}, \beta_{3}, \beta_{4} & =\text { Koefisien } \\ \mathrm{e} & =\text { error }\end{array}$

\section{HASIL DAN PEMBAHASAN}

Validnya suatu kuesioner dilihat pada Correlated Item - Total Correlation, jika nilai pearson correlation $>0,30$. Berdasarkan hasil uji validitas, nilai pearson correlation pengalaman kerja, yaitu $0,480-0,718>0,30$. Nilai pearson correlation kompleksitas tugas, yaitu $0,572-0,714>0,30$. Nilai pearson 
correlation pengalaman kerja, yaitu 0,651 - 0,791 > 0,30. Jadi, seluruh instrumen dikatakan valid dan layak digunakan sebagai alat ukur.

Instrumen dapat dinyatakan reliabel jika nilai Cronbach's Alpha diatas 0,70. Berdasarkan uji reliabilitas, nilai Cronbach's Alpha pengalaman kerja adalah 0,717, nilai Cronbach's Alpha kompleksitas tugas adalah 0,715, dan nilai Cronbach's Alpha dari efektivitas pengguna sistem informasi akuntansi adalah 0,898. Berdasarkan hasil tersebut apat dinyatakan bahwa seluruh variabel dinyatakan reliabel sehingga dapat digunakan untuk melakukan penelitian. Statistik deskriptif digunakan untuk memberikan informasi mengenai bagaimana karakteristik variabel, yaitu jumlah pengamatan, nilai minimum, nilai maksimum, nilai mean, dan standar deviasi.

Tabel 3.

Hasil Analisis Statistik Deskriptif

\begin{tabular}{lrrrrr}
\hline & N & \multicolumn{1}{c}{ Minimum } & Maximum & \multicolumn{1}{c}{ Mean } & Std. Deviation \\
\hline Usia & 69 & 1.00 & 4.00 & 2.8986 & .95709 \\
Pengalaman Kerja & 69 & 9.00 & 21.00 & 14.3478 & 2.29978 \\
Tingkat Pendidikan & 69 & 1.00 & 3.00 & 1.7681 & .92585 \\
Kompleksitas Tugas & 69 & 11.00 & 22.00 & 15.5797 & 2.06088 \\
Efektivitas Pengguna SIA & 69 & 12.00 & 40.00 & 31.0435 & 4.56146 \\
Valid N (listwise) & 69 & & & & \\
\hline
\end{tabular}

Sumber: Data diolah, 2017

Menurut Tabel 3, usia $\left(\mathrm{X}_{1}\right)$ memiliki nilai minimum sebesar 1,00 (menunjukkan usia 21-30 tahun) dan nilai maksimum sebesar 4,00 (menunjukkan usia lebih dari 50 tahun), dan nilai rata-rata sebesar 2,90. Nilai rata-rata 2,90 menunjukkan usia responden cenderung tinggi, yaitu antara usia 40-50 tahun karena nilai rata-rata 2,90 berada di antara nilai 2,00 (menunjukkan usia 31-40 tahun) dan nilai 3,00 (menunjukkan usia 41-50 tahun). Standar deviasi usia adalah 0,96 . 
Pengalaman kerja $\left(\mathrm{X}_{2}\right)$ memiliki nilai minimum sebesar 9,00 dan nilai maksimum sebesar 21,00 , dan nilai rata-rata sebesar 14,35 . Nilai rata-rata 14,35 menunjukkan bahwa responden cenderung setuju terhadap item-item pernyataan yang berarti pengalaman kerja cenderung tinggi. Standar deviasi pengalaman kerja adalah 2,30.

Tingkat pendidikan $\left(\mathrm{X}_{3}\right)$ memiliki nilai minimum sebesar 1,00 (menunjukkan tingkat pendidikan SMA/SMK/SLTA) dan nilai maksimum sebesar 3,00 (menunjukkan tingkat pendidikan S1), dan nilai rata-rata sebesar 1,77. Nilai rata-rata 1,77 berarti bahwa tingkat pendidikan responden cenderung tinggi, yaitu pendidikan dengan jenjang antara SMA/SMK/SLTA atau diploma karena nilai rata-rata 1,77 berada di antara nilai 1,00 (menunjukkan tingkat pendidikan SMA/SMK/SLTA) dan nilai 2,00 (menunjukkan tingkat pendidikan Diploma). Standar deviasi pengalaman kerja adalah 0,92.

Kompleksitas tugas $\left(\mathrm{X}_{4}\right)$ memiliki nilai minimum sebesar 11,00 dan nilai maksimum sebesar 22,00, dan nilai rata-rata sebesar 15,58 . Nilai rata-rata 15,58 menunjukkan bahwa responden cenderung setuju pada item-item pernyataan, yang berarti kompleksitas tugas cenderung tinggi. Standar deviasi pengalaman kerja adalah 2,06. Efektivitas pengguna SIA (Y) memiliki nilai minimum sebesar 12,00 dan nilai maksimum sebesar 40,00, dan nilai rata-rata sebesar 31,04. Nilai ratarata 31,04 menunjukkan bahwa responden cenderung setuju pada item-item pernyataan, yang berarti efektivitas pengguna SIA cenderung tinggi. Standar deviasi efektivitas pengguna SIA adalah sebesar 4,56. Sebelum melakukan 
analisis data dengan model regresi, uji asumsi klasik perlu dilakukan, yang meliputi uji normalitas, uji multikolinearitas, dan juga uji heteroskedastisitas.

Tabel 4.

Hasil Uji Normalitas

\begin{tabular}{llr}
\hline & & $\begin{array}{c}\text { Unstandardized } \\
\text { Residual }\end{array}$ \\
\hline Normal Parameters & & 69 \\
Most Extreme Differences & Mean & -.3981126 \\
& Std. Deviation & 3.09548189 \\
Test Statistic & Absolute & .094 \\
Asymp. Sig. (2-tailed) & Positive & .094 \\
Sumber: Data diolah, 2017 & Negative & -.063 \\
& & .094 \\
& & $.200^{\mathrm{c}, \mathrm{d}}$ \\
\hline
\end{tabular}

Berdasarkan Tabel 4, nilai Asymp. Sig. (2-tailed) adalah 0,200>0,05 yang berarti data terdistribusi secara normal.

Tabel 5.

Hasil Uji Multikolinearitas

\begin{tabular}{llcc}
\hline Model & \multicolumn{2}{c}{ Collinearityt Statistics } \\
\cline { 3 - 4 } & Usia & Tolerance & VIF \\
\hline Pengalaman Kerja & 0,747 & 1,339 \\
& Tingkat Pendidikan & 0,801 & 1,248 \\
& Kompleksitas Tugas & 0,835 & 1,197 \\
& 0,802 & 1,246 \\
\hline
\end{tabular}

Sumber: Data diolah, 2017

Berdasarkan Tabel 5, nilai tolerance dan nilai VIF setiap variabel. Hasil di atas menunjukkan bahwa nilai tolerance seluruh variabel $>10 \%$ dan nilai VIF seluruh variabel $<10$, sehingga dinyatakan bahwa data pada penelitian ini tidak memiliki gejala multikolinearitas.

Tabel 6.

Hasil Uji Heteroskdastisitas

\begin{tabular}{llcl}
\hline \multicolumn{1}{c}{ Model } & Sig & Keterangan \\
\hline 1 & (Costant) & 0,371 & \\
& Usia & 0,143 & Terbebas Heteroskedastisitas \\
& Pengalaman Kerja & 0,152 & Terbebas Heteroskedastisitas \\
Tingkat Pendidikan & 0,278 & Terbebas Heteroskedastisitas \\
& Kompleksitas Tugas & 0,190 & Terbebas Heteroskedastisitas \\
\hline
\end{tabular}

Sumber: Data diolah, 2017 
Berdasarkan Tabel 6, tingkat signifikansi untuk semua variabel di atas 0,05 berarti dapat dikatakan bahwa dalam model regresi ini tidak terdapat heteroskedastisitas.

Table 7.

Hasil Uji Regresi Linear Berganda

\begin{tabular}{|c|c|c|c|c|c|}
\hline \multirow[t]{2}{*}{ Variabel } & \multicolumn{2}{|c|}{$\begin{array}{l}\text { Undstandardized } \\
\text { Coefficients }\end{array}$} & \multirow{2}{*}{$\begin{array}{c}\text { Standardized } \\
\text { Coefficients } \\
\text { Beta }\end{array}$} & \multirow[t]{2}{*}{$T$} & \multirow[t]{2}{*}{ Sig. } \\
\hline & B & Std. Error & & & \\
\hline Usia & $-1,312$ & 0,471 & $-0,275$ & $-2,785$ & 0,007 \\
\hline Pengalaman Kerja & 0,562 & 0,189 & 0,283 & 2,970 & 0,004 \\
\hline Tingkat Pendidikan & 1,214 & 0,460 & 0,246 & 2,638 & 0,010 \\
\hline Kompleksitas Tugas & $-0,542$ & 0,211 & $-0,245$ & $-2,569$ & 0,013 \\
\hline Constant & $=33,079$ & & & & \\
\hline $\mathrm{R}$ & $=0,730$ & & & & \\
\hline Adjusted R square & $=0,504$ & & & & \\
\hline $\mathrm{F}$ & $=18,293$ & & & & \\
\hline Sig. F & $=0,000$ & & & & \\
\hline
\end{tabular}

Nilai konstanta sebesar 33,079 menunjukkan bahwa bila usia $\left(\mathrm{X}_{1}\right)$, pengalaman kerja $\left(\mathrm{X}_{2}\right)$, tingkat pendidikan $\left(\mathrm{X}_{3}\right)$, dan kompleksitas tugas $\left(\mathrm{X}_{4}\right)$ adalah nol, maka efektivitas pengguna sistem informasi akuntansi sama dengan 33,079. Nilai koefisien $\beta_{1}=-1,312$ memiliki tanda negatif yang menunjukkan setiap bertambahnya usia $\left(\mathrm{X}_{1}\right)$, maka terdapat kecenderungan penurunan efektivitas pengguna sistem informasi akuntansi (Y) dengan asumsi bahwa variabel lainnya konstan. Nilai koefisien $\beta_{2}=0,562$ memiliki tanda positif yang menunjukkan setiap bertambahnya pengalaman kerja $\left(\mathrm{X}_{2}\right)$, maka terdapat kecenderungan peningkatan efektivitas pengguna sistem informasi akuntansi (Y) dengan asumsi bahwa variabel lainnya konstan. Nilai koefisien $\beta_{3}=1,214$ memiliki tanda positif yang menunjukkan setiap bertambahnya tingkat pendidikan $\left(\mathrm{X}_{3}\right)$, maka terdapat kecenderungan peningkatan efektivitas pengguna sistem informasi akuntansi (Y) dengan asumsi bahwa variabel lainnya konstan. Nilai 
koefisien $\beta_{4}=-0,542$ memiliki tanda negatif yang menunjukkan setiap bertambahnya kompleksitas tugas $\left(\mathrm{X}_{4}\right)$, maka terdapat kecenderungan penurunan efektivitas pengguna sistem informasi akuntansi (Y) dengan asumsi bahwa variabel lainnya konstan.

Berdasarkan Tabel 7, signifikansi $\mathrm{F}$ atau $\mathrm{P}$ value sebesar $0,00<$ nilai $\alpha=$ 0,05. Hal ini berarti model penelitian layak atau dapat digunakan sebagai alat analisis. Dengan demikian, usia, pengalaman kerja, tingkat pendidikan, dan kompleksitas tugas berpengaruh terhadap efektivitas pengguna sistem informasi akuntansi. Berdasarkan Tabel 7, nilai Adjusted $R^{2}$ adalah 50,4 persen yang menunjukan pengaruh usia, pengalaman kerja, tingkat pendidikan, dan kompleksitas tugas terhadap efektivitas penggunan sistem informasi akuntansi adalah 50,4 persen. Sisanya, yaitu $100 \%-50,4 \%=49,6$ persen dipengaruhi oleh faktor lainnya.

Berdasarkan Tabel 7, nilai signifikansi uji t untuk variabel pengaruh usia terhadap efektivitas pengguna sistem informasi akuntansi sebesar $0,007<\alpha=0,05$ dan nilai koefisien regresi adalah -1,312. Ini menunjukan bahwa usia berpengaruh signifikan negatif terhadap efektivitas pengguna sistem informasi akuntansi, sehingga hipotesis pertama diterima. Hasil tersebut sesuai dengan hasil penelitian Widyatmoko dan Pramudi (2011), yaitu usia berpengaruh secara signifikan negatif terhadap penggunaan komputer. Wirjono (2010) menyatakan bahwa usia adalah faktor intrinsik yang dapat mempengaruhi penggunaan sistem informasi baru. Perbedaan usia berkaitan dengan kesulitan memproses stimuli kompleks dan mengalokasikan perhatian kepada informasi. Kebutuhan berkumpul 
meningkat dengan bertambahnya usia akan lebih terpengaruh oleh pengaruh sosial serta menurunnya pengalaman.

Berdasarkan Tabel 7, pada nilai signifikansi uji t untuk pengaruh variabel pengalaman kerja terhadap efektivitas pengguna sistem informasi akuntansi sebesar $0,004<$ dari $\alpha=0,05$ dan nilai koefisien regresi adalah 0,562 . Hal tersebut menunjukan bahwa pengalaman kerja berpengaruh signifikan positif terhadap efektivitas pengguna sistem informasi akuntansi yang berarti hipotesis kedua diterima. Hasil tersebut sesuai dengan hasil penelitian yang dilakukan Vipraprastha dan Sari (2016), yaitu pengalaman kerja berpengaruh positif terhadap efektivitas sistem informasi akuntansi. Semakin tinggi pengalaman kerja, maka semakin efektif penggunaan sistem informasi akuntansi oleh karyawan. Widyantari dan Suardikha (2016) menyatakan bahwa pengalaman kerja berpengaruh terhadap karakter bekerja dimana semakin lama seseorang bekerja dengan sistem informasi akuntansi maka akan semakin baik kinerjanya dalam proses penyajian informasi akuntansi.

Berdasarkan Tabel 7, pada nilai signifikansi uji t untuk pengaruh variabel tingkat pendidikan terhadap efektivitas pengguna sistem informasi akuntansi sebesar $0,010<\alpha=0,05$ dan nilai koefisien regresi adalah 1,214. Hal tersebut menunjukan bahwa tingkat pendidikan berpengaruh signifikan positif terhadap efektivitas pengguna sistem informasi akuntansi, hipotesis ketiga diterima. Hasil tersebut sesuai dengan hasil penelitian Dwijayanthi dan Dharmadiaksa (2013), yaitu tingkat pendidikan berpengaruh positif dan signifikan terhadap kinerja individu pengguna sistem informasi akuntansi. Vipraprastha dan Sari (2016) 
Putu Widya Anjani dan Ni Gusti Putu Wirawati. Pengaruh...

mengatakan pendidikan merupakan usaha untuk dapat meningkatkan pengetahuan. Pendidikan adalah optimalisasi sumber daya manusia mengenai antisipasi kemampuan dan keahlian individu untuk mengantisipasi perubahan.

Berdasarkan Tabel 7, pada nilai signifikansi uji t untuk variabel pengaruh kompleksitas tugas terhadap efektivitas pengguna sistem informasi akuntansi sebesar $0,013<\alpha=0,05$ dan nilai koefisien regresi adalah $-0,542$. Hal tersebut menunjukan bahwa kompleksitas tugas berpengaruh signifikan negatif terhadap efektivitas pengguna sistem informasi akuntansi, sehingga hipotesis keempat diterima. Hasil tersebut sesuai dengan yang dikatakan Prajanti, dkk (2014), yaitu kompleksitas tugas dapat membuat seorang karyawan menjadi tidak konsistensi dan tidak akuntabilitas. Semakin kompleks dan rumit tugas dapat mempersulit karyawan dalam mengerjakan tugasnya sehingga karyawan menjadi tidak konsisten untuk menggunakan sistem informasi akuntansi yang ada. Kesalahankesalahan yang terjadi semakin banyak seiring bertambahnya tugas yang dikerjakan oleh karyawan.

\section{SIMPULAN}

Berdasarkan seluruh pembahasan, kesimpulan yang dapat diambil adalah usia dan kompleksitas tugas berpengaruh negatif terhadap efektivitas pengguna sistem informasi akuntansi. Semakin tinggi usia dan komplekitas tugas, maka dapat menurunkan efektivitas pengguna sistem informasi akuntansi. Sedangkan pengalaman kerja dan tingkat pendidikan berpengaruh positif terhadap efektivitas pengguna sistem informasi akuntansi. Semakin tinggi pengalaman kerja dan 
tingkat pendidikan yang dimiliki karyawan, dapat meningkatkan efektivitas pengguna sistem informasi akuntansi.

\section{REFERENSI}

Abduljalil, Khalil dan Yuserrie Zainuddin. 2015. Intrinsic and Extrinsic Motivation as Attitude Factors towards Adoption of Accounting Information System (AIS) In Libyan SMEs. International Journal of Academic Research in Accounting, Finance and Management Sciences Vol. 5, No.1, January 2015, pp. 161-170.

Ayuni, Nurul Dwi. 2008. Pengaruh Pendidikan, Pelatihan, dan Pengalaman Auditor terhadap Kualitas Audit atas Sistem Informasi Berbasis Komputer. Skripsi Sarjana Jurusan Akuntansi Fakultas Ekonomi dan Ilmu Sosial Universitas Islam Negeri Syarif Hidayatullah.

Baswir, Revrisond. 2013. Koperasi Indonesia. Yogyakarta : BPFEYOGYAKARTA

Bodnar, George H. dan William S. Hopwood. 2006. Sistem Informasi Akuntansi Edisi 9. Yogyakarta : Andi.

Bonollo, Elisa, Simone Lazzini, Mara Zuccardi Merli. 2015. Innovations in Accounting Information System in the Public Sector. Evidences from Italian Public Universities. Genoa : LNISO, volume 14.

Budiono, Akhmad Edi. 2004. Pengaruh Faktor Demografi dan Personality terhadap Keahlian dalam End-User Computing di Jawa Tengah. Tesis Magister Akuntansi Program Pasca Sarjana Universitas Diponegoro, Semarang.

Dandago, Kabiru I. dan Abdullahi Sani Rufai. 2014. Information Technology and Accounting Information. Asian Economic and Financial Review, 4(5):655-670.

Dwijayanthi, Diah Maha dan I.B. Dharmadiaksa. 2013. Pengaruh Insentif, Tingkat Pendidikan, Pelatihan dan Pengalaman Kerja pada Kinerja Individu Pengguna Sistem Informasi Akuntansi SKPD Dispenda Kota Denpasar. Denpasar : E-Jurnal Akuntansi Universitas Udayana 4.2 (2013): 332-344.

Dwitrayani, Made Christin, A.A.G.P. Widanaputra, dan I.G.A. Made Asri Dwija Putri. 2017. Pengaruh Kecanggihan Teknologi Informasi, Partisipasi Manajemen, Budaya Organisasi dan Kepuasan Pengguna pada Efektivitas Sistem Informasi Akuntansi Bank Perkreditan Rakyat di Kabupaten Badung. Denpasar : E-Jurnal Ekonomi dan Bisnis Universitas Udayana 6.1 (2017): 197-222. 
Fatmawati, Endang. 2015. Technology Acceptance Model (TAM) untuk Menganalisis Penerimaan terhadap Sistem Informasi Perpustakaan. Sumatera Utara : Jurnal Iqra' Volume 09 No.01 Mei, 201 Universitas Islam Negeri Sumatera Utara.

Hariwangsa, I Putu Gede Bagus dan Ni Gusti Putu Wirawati. 2017. Pengaruh Efektivitas Modal Sendiri, Likuiditas, dan Solvabilitas Terhadap Tingkat Rentabilitas pada Koperasi. Denpasar : E-Jurnal Akuntansi Universitas Udayana Vol.20.3. September (2017): 2392-2420

Ilirjan, Rudina Rama, dan Xhiliola Agaraj. 2015. Implications of Accounting Information System Implementation in SMEs: A Study on Retail Business in Vlore Region. Mediterranean Journal of Social Sciences Vol 6 No 3.

Indriantoro, Nur dan Bambang Supomo. 2016. Metodologi Penelitian Bisnis untuk Akuntansi dan Manajemen.Edisi Pertama. Yogyakarta : BPFEYogyakarta.

Ismail, Noor Azizi dan Malcolm King. 2007. Factors Influencing The Alignment of Accounting Information Systems in Small and Medium Sized Malaysian Manufacturing Firms. Journal of Information Systems and Small Business vol. 1, no. 1-2, pp. 1-20.

Khairi, Mohammad Shadiq dan Zaki Baridwan. 2015. An Empirical Study on Organizational Acceptance Accounting Information Systems in Sharia Banking. Universitas Brawijaya : The International Journal of Accounting and Business Society Vol. 23, No. 1 August 2015.

Miller, Rachelle Paige, Esther Bunn, dan Kelly Noe. 2016. Accounting Information Systems: A View from the Public Eye. International Business \& Economics Research Journal - September/October 2016 Volume 15, Number 5.

Morris, Michael G. dan Viswanath Venkatesh. 2000. Age Differences in Technology Adoption Decisions : Implications for A Changing Work Force. Personnel Psychology: Volume 53, Issue 2.

Parjanti, Eny, Kartika Hendra Ts, dan Siti Nurlela. 2014. Pengaruh Sistem Informasi Akuntansi, Gaya Kepemimpinan dan Kompleksitas Tugas terhadap Kinerja. Surakarta : Jurnal Paradigma Februari - Juli 2014 Fakultas Ekonomi Jurusan Akuntansi Universitas Islam Batik Surakarta Vol. 12, No. 01.

Prasad, Acklesh dan Peter Green. 2015. Organizational Competencies and Dynamic Accounting Information System Capability: Impact on AIS Processes and Firm Performance. Briebane : Journal of Information 
Systems Fall 2015 Queensland University of Technology, Vol. 29, No. 3, pp. 123-149.

Pratama, Gede Aditya Puja dan I Made Sadha Suardhika. 2013. Keahlian Pemakai Komputer dan Kenyamanan Fisik dan Tingkat Efektivitas Sistem Informasi Akuntansi terhadap Kinerja Karyawan. Denpasar : E-Jurnal Akuntansi Universitas Udayana 5.2 (2013): 361-381.

Setiawan, Satrio Adi. 2010. Pengaruh Umur, Pendidikan, Pendapatan, Pengalaman Kerja dan Jenis Kelamin terhadap Lama Mencari Kerja Bagi Tenaga Kerja Terdidik di Kota Magelang. Skripsi Sarjana Jurusan Ilmu Ekonomi dan Ekonomi Pembangunan Universitas Diponegoro.

Seyal, Afzaal H. dan Noah Abd Rahman. 2015. A Preliminary Investigation of Measuring Users Satisfaction \& Success on Financial \& Accounting Information System: Bruneian Perspective. International Journal of Business and Management Review Vol.3, No.2, pp.1-22, December 2015.

Siswosoebrotho, Kezia Hapsari dan Sri Daryanti. 2013. Aplikasi Theory of Reasoned Action dengan Pengaruh Keahlian Salesperson dan Trust Belief pada Drugstore terhadap Minat Konsumen untuk Membeli Nutrasetika. Jakarta : Fakultas Ekonomi Universitas Indonesia.

Srivastava, Priya dan Lognathan. 2016. Impact of Accounting Information for Management Decision Making. International Journal of Applied Research 2016; 2(5): 171-174.

Suartika, Kamajaya Adi dan Ni Luh Sari Widhiyani. 2017. Kemampuan Teknik Personal pada Efektivitas Penggunaan Sistem Informasi Akuntansi dengan Pendidikan dan Pelatihan sebagai Pemoderasi. Denpasar : EJurnal Akuntansi Universitas Udayana Vol.18.2. Februari (2017): 14851512.

Sugiyono. 2014. Metodelogi Penelitian Kuantitatif Kualitatif dan R\&D. Bandung: Alpha Beta.

Supatmi dan Febrian Martinus. 2014. Pengaruh Faktor - Faktor Pemanfaatan Teknologi Informasi terhadap Kinerja Individual pada KPP Pratama Salatiga. Skripsi Sarjana Jurusan Akuntansi Fakultas Ekonmika dan Bisnis Universitas Kristen Satya Wacana.

Tazik, Hassan dan Zakiah Muhammadun Mohamed. 2014. Accounting Information System Effectiveness, Foreign Ownership and Timeliness of Corporate Financial Report. Kuala Lumpur : Proceedings of 5th AsiaPacific Business Research Conference 17 - 18 February, 2014, Hotel Istana, Kuala Lumpur, Malaysia, ISBN: 978-1-922069-44-3. 
Uyar, Ali, Ali Haydar Gungormus dan Cemil Kuzey. 2017. Impact of the Accounting Information System on Corporate Governance: Evidence from Turkish Non-Listed Companies. Australasian Accounting Business \& Finance Journal; Wollongong 11.1 (2017): 9-27.

Vipraprastha, Tiksnayana dan Maria M.Ratna Sari. 2016. Pengaruh Faktor-Faktor Kinerja Individual Karyawan Terhadap Efektivitas Penggunaan Sistem Informasi Akuntansi. Denpasar : E-Jurnal Akuntansi Universitas Udayana Vol.15.3.Juni (2016):1826-1855.

Widyantari, Ni Wayan Lisna dan I Made Sadha Suardikha. 2016. Pengaruh Pelatihan dan Pendidikan, Pengalaman Kerja dan Partisipasi Manajemen pada Efektivitas Penggunaan Sistem Informasi Akuntansi. Denpasar : EJurnal Akuntansi Universitas Udayana Vol.17.2. November (2016): 1546-1574.

Widyatmoko, Karis dan Y. Tyas Gatur Pramudi. 2011. Pengaruh Karakteristik Individu, Sikap, dan Pelatihan Terhadap Penggunaan Teknologi Informasi dan Kinerja Pegawai Kelurahan Menuju Terwujudnya EGovernment. Semarang : Jurnal Dian Vol 11, No 1 (2011).

Wirjono, Endang Raino. 2010. Pengaruh Kepercayaan dan Umur terhadap Kinerja Individual dalam Penggunaan Teknologi Informasi. Denpasar : Jurnal Ilmiah Akuntansi dan Bisnis Januari 2010 Fakultas Ekonomi dan Bisnis Universitas Udayana Vol. 5, No. 1. 